University of Nebraska - Lincoln

DigitalCommons@University of Nebraska - Lincoln

1987

\title{
Chromate Adsorption on Amorphous Iron Oxyhydroxide in the Presence of Major Groundwater lons
}

John M. Zachara

Pacific Northwest National Laboratory, john.zachara@pnl.gov

Donald Girvln

Pacific Northwest National Laboratory

Ronald Schmidt

Pacific Northwest National Laboratory

C. Thomas Resch

Pacific Northwest National Laboratory

Follow this and additional works at: https://digitalcommons.unl.edu/usdoepub

Part of the Bioresource and Agricultural Engineering Commons

Zachara, John M.; Girvln, Donald; Schmidt, Ronald; and Resch, C. Thomas, "Chromate Adsorption on Amorphous Iron Oxyhydroxide in the Presence of Major Groundwater lons" (1987). US Department of Energy Publications. 204.

https://digitalcommons.unl.edu/usdoepub/204

This Article is brought to you for free and open access by the U.S. Department of Energy at DigitalCommons@University of Nebraska - Lincoln. It has been accepted for inclusion in US Department of Energy Publications by an authorized administrator of DigitalCommons@University of Nebraska - Lincoln. 


\title{
Chromate Adsorption on Amorphous Iron Oxyhydroxide in the Presence of Major Groundwater Ions
}

\author{
John M. Zachara, * Donald C. Girvin, Ronald L. Schmidt, and C. Thomas Resch
}

Battelle, Pacific Northwest Laboratories, Richland, Washington 99352

\begin{abstract}
- Chromate adsorption on amorphous iron oxyhydroxide was investigated in dilute iron suspensions as a single solute and in solutions of increasing complexity containing $\mathrm{CO}_{2}(\mathrm{~g}), \mathrm{SO}_{4}{ }^{2-}(\mathrm{aq}), \mathrm{H}_{4} \mathrm{SiO}_{4}(\mathrm{aq})$, and cations $\left[\mathrm{K}^{+}, \mathrm{Mg}^{2+}\right.$, $\left.\mathrm{Ca}^{2+}(\mathrm{aq})\right]$. In paired-solute systems (e.g., $\mathrm{CrO}_{4}{ }^{2-}-\mathrm{H}_{2} \mathrm{CO}_{3}{ }^{*}$ ), anionic cosolutes markedly reduce $\mathrm{CrO}_{4}{ }^{2-}$ adsorption through a combination of competitive and electrostatic effects, but cations exert no appreciable influence. Additionally, $\mathrm{H}_{4} \mathrm{SiO}_{4}$ exhibits a strong time-dependent effect: $\mathrm{CrO}_{4}{ }^{2-}$ adsorption is greatly decreased with increasing $\mathrm{H}_{4} \mathrm{SiO}_{4}$ contact time. In multiple-ion mixtures, each anion added to the mixture decreases $\mathrm{CrO}_{4}{ }^{2-}$ adsorption further. Adsorption constants for the individual reactive solutes were used in the triple-layer model. The model calculations are in good agreement with the $\mathrm{CrO}_{4}{ }^{2-}$ adsorption data for paired- and multiple-solute systems. However, the model calculations underestimate $\mathrm{CrO}_{4}{ }^{2-}$ adsorption when surface site saturation is approached. Questions remain regarding the surface interactions of both $\mathrm{CO}_{2}(\mathrm{aq})$ and $\mathrm{H}_{4} \mathrm{SiO}_{4}$. The results have major implications for the adsorption behavior of $\mathrm{CrO}_{4}^{2-}$ and other oxyanions in subsurface waters.
\end{abstract}

\section{Introduction}

Hexavalent chromium $\left(\mathrm{CrO}_{4}{ }^{2-}\right)$ is an antibiofoulant and anticorrosive agent and is common in industrial wastewaters. Dissolved $\mathrm{CrO}_{4}^{2-}$ is toxic to many organisms at low aqueous concentration (1) and is a regulated constituent in domestic water supplies (2). Chromate-containing wastes are often disposed of to the land surface or, as part of a complex aqueous solute mixture, to waste ponds or lagoons. These practices lead to concern over $\mathrm{CrO}_{4}{ }^{2-}$ migration to and within nearby groundwaters.

Mineral phases with proton-specific surface sites, particularly those with high zero points of charge (e.g., iron and aluminum oxides), may effectively adsorb $\mathrm{CrO}_{4}{ }^{2-}$ from $\mathrm{pH} 2$ to $\mathrm{pH} 7$ (3-7). Like other weak acid oxyanions (e.g., $\mathrm{SeO}_{4}{ }^{2-}, \mathrm{SO}_{4}{ }^{2-}$, and $\mathrm{AsO}_{4}{ }^{3-}$,, $\mathrm{CrO}_{4}{ }^{2-}$ adsorption is $\mathrm{pH}$ dependent on these adsorbents, reflecting the charging of the adsorbent surface and solute speciation. Amorphous iron oxide $\left[\mathrm{Fe}_{2} \mathrm{O}_{3} \cdot \mathrm{H}_{2} \mathrm{O}(\mathrm{am})\right]$ or ferrihydrite, a common surface coating of subsoil particles, has a particularly high capacity for $\mathrm{Cr}(\mathrm{VI})$, reaching $0.1 \mathrm{~mol}$ of $\mathrm{Cr} / \mathrm{mol}$ of $\mathrm{Fe}$ at a solution $\mathrm{pH}$ of $<5.5$ (5). This capacity reflects the high surface area and site density of $\mathrm{Fe}_{2} \mathrm{O}_{3} \cdot \mathrm{H}_{2} \mathrm{O}(\mathrm{am})$.

Despite the strong adsorption affinity of $\mathrm{CrO}_{4}{ }^{2-}$ for certain proton-specific mineral surfaces, it is mobile in soil and subsurface systems $(8-10)$. The presence of other competing anions may reduce $\mathrm{CrO}_{4}{ }^{2-}$ adsorption and thus increase its mobility. Preliminary evidence suggests that solute interactions may be significant. Cosorption of $\mathrm{SO}_{4}^{2-}$ on $\mathrm{Fe}_{2} \mathrm{O}_{3} \cdot \mathrm{H}_{2} \mathrm{O}(\mathrm{am})$ reduces $\mathrm{CrO}_{4}{ }^{2-}$ adsorption by as much as $80 \%$ (5). Phosphate and selinite compete on goethite (11). Similarly, a ligand-exchange model suggests that anion adsorption on goethite in natural lakewater is largely controlled by silicate and phosphate sorption, which influence adsorbent surface speciation and charge $(12,13)$. These limited observations and the wide range of inorganic ions ranging up to $10^{-2} \mathrm{M}$ in natural waters suggest the need for improved understanding of $\mathrm{CrO}_{4}{ }^{2-}$ adsorption from complex solute mixtures.
This paper reports the adsorption of $\mathrm{CrO}_{4}{ }^{2-}$ at typical environmental concentrations on $\mathrm{Fe}_{2} \mathrm{O}_{3} \cdot \mathrm{H}_{2} \mathrm{O}(\mathrm{am})$ in the presence of common cations and anions present in groundwater $\left(\mathrm{K}^{+}, \mathrm{Mg}^{2+}, \mathrm{Ca}^{2+}, \mathrm{SO}_{4}{ }^{2-}, \mathrm{CO}_{2}(\mathrm{aq}), \mathrm{H}_{4} \mathrm{SiO}_{4}\right)$. Single-solute equilibrium adsorption constants for $\mathrm{CrO}_{4}^{2-}$, $\mathrm{SO}_{4}{ }^{2-}, \mathrm{Ca}^{2+}, \mathrm{CO}_{2}(\mathrm{aq}), \mathrm{Na}^{+}$, and $\mathrm{NO}_{3}{ }^{-}$derived under $\mathrm{N}_{2}(\mathrm{~g})$ atmosphere are used in the triple-layer adsorption model (TLM) (14) to simulate $\mathrm{CrO}_{4}{ }^{2-}$ adsorption in the presence of single and multiple interacting ions.

\section{Experimental Procedures}

Synthesis of $\mathrm{Fe}_{2} \mathrm{O}_{3} \cdot \mathrm{H}_{2} \mathrm{O}$ (am). Amorphous iron oxide $\left[\mathrm{Fe}_{2} \mathrm{O}_{3} \cdot \mathrm{H}_{2} \mathrm{O}(\mathrm{am})\right]$ was prepared in a jacketed reaction flask (at $25^{\circ} \mathrm{C}$ ) by hydrolysis of a sparged $0.1 \mathrm{M} \mathrm{Fe}\left(\mathrm{NO}_{3}\right)_{3}$ solution. An automatic titration system was used to add the base $\left[1.0 \mathrm{M} \mathrm{NaOH}, \mathrm{CO}_{2}\right.$ (g)-free as determined by analysis] at a constant rate up to $\mathrm{pH} 7.25$. Carbonate-free conditions were maintained during precipitation by using a glovebox with $\mathrm{N}_{2}$ atmosphere or, more commonly, by using a partially sealed reaction flask with continuous $\mathrm{N}_{2}$ sparge to prevent air intrusion. The suspension was allowed to equilibrate under $\mathrm{N}_{2}$ atmosphere $\left(25^{\circ} \mathrm{C}\right)$ for 14 $h$ before use.

Adsorption Experiments. (A) Basic Procedure. Adsorption experiments were conducted in a jacketed 500 -mL reaction flask that had been "presaturated" with $\mathrm{Cr}$ (VI) to eliminate potential adsorption by the flask during the experiment. The temperature was kept constant (at $25^{\circ} \mathrm{C}$ ) with a recirculating water bath. The $\mathrm{Fe}_{2} \mathrm{O}_{3} \cdot \mathrm{H}_{2} \mathrm{O}$ (am) suspension was placed in the reaction vessel with an electrolyte $\left(0.1 \mathrm{M} \mathrm{NaNO}_{3}\right)$ and equilibrated $(1 \mathrm{~h})$ under $\mathrm{N}_{2}$ atmosphere at $\mathrm{pH}$ 9.0-9.5 where no sorption was anticipated, after which time the appropriate solutes and ${ }^{51} \mathrm{Cr}$ (approximately $5000 \mathrm{cpm} / \mathrm{mL}$ ) were added. An aliquot was immediately removed as a counting standard for the adsorbate, and the $\mathrm{pH}$ of the suspension was incrementally adjusted downward. Duplicate samples of the suspensions were removed at the desired $\mathrm{pH}$ levels, placed in $\mathrm{N}_{2}$-sparged Corex (Corning Glass Works, Houghton Park, NY) centrifuge tubes (35 mL), and shaken for $4 \mathrm{~h}$ in a controlled-environment shaker $\left(\mathrm{N}_{2}\right.$ atmosphere, 25 ${ }^{\circ} \mathrm{C}$ ). The final $\mathrm{pH}$ was then measured in stirred suspensions under $\mathrm{N}_{2}$ atmosphere with a Ross combination $\mathrm{pH}$ electrode, and aliquots of the supernate were analyzed. The activity of ${ }^{51} \mathrm{Cr}$ was determined by a Packard $\gamma$ spectrophotometer with an NaI well crystal. The quantity adsorbed was the difference between the initial and final concentrations.

(B) Single- and Paired-Solute Adsorption. Chromate adsorption $\left(5.0 \times 10^{-6} \mathrm{M}\right)$ was measured at $0.87 \times$ $10^{-3}$ and $17.4 \times 10^{-3} \mathrm{M}$ total iron. Inorganic carbon adsorption $\left(\left[\mathrm{C}_{\mathrm{T}}\right]=4.6 \times 10^{-6} \mathrm{M}\right)$ was measured in similar iron suspensions spiked with $\mathrm{NaHCO}_{3}-\mathrm{NaH}^{14} \mathrm{CO}_{3}$ over a $\mathrm{pH}$ range of 5.5-9. The tightly sealed individual centrifuge tubes with zero headspace stood for $24 \mathrm{~h}$ before carbonate adsorption was measured by ${ }^{14} \mathrm{C}$ scintillation counting of ${ }^{14} \mathrm{C}$. The constancy of $\left[\mathrm{C}_{\mathrm{T}}\right]$ was confirmed by directly analyzing some samples for total inorganic carbon.

Chromate adsorption in the presence of $\mathrm{CO}_{2}(\mathrm{~g})$ was investigated in a glovebox filled with a $\mathrm{CO}_{2} / \mathrm{N}_{2}$ mixture containing $P_{\mathrm{CO}_{2}}=10^{-2.46} \mathrm{~atm}$. The $350-\mathrm{mL}$ suspensions 


\section{Table I. Triple-Layer Model Parameters for $\mathrm{Fe}_{2} \mathrm{O}_{3} \bullet \mathrm{H}_{2} \mathrm{O}(\mathrm{am})$ Used in This Study}

surface site density $\left(N_{\mathrm{s}}\right)^{a}$ surface area $(S)^{b}$

outer-layer capacitance $\left(C_{2}\right)^{a}$

inner-layer capacitance $\left(C_{1}\right)^{b}$

11 sites $/ \mathrm{nm}^{2}(9.8 \mathrm{mmol}$ of sites $/ \mathrm{g} \mathrm{Fe})$ $600 \mathrm{~m}^{2} / \mathrm{g}$

$0.20 \mathrm{~F} / \mathrm{m}^{2}$

$1.25 \mathrm{~F} / \mathrm{m}^{2}$

${ }^{a}$ Davis et al. (14). ${ }^{b}$ Girvin et al. (15).

\section{Table II. Surface Complexation Reactions and}

Triple-Layer Model Constants for $\mathrm{Fe}_{2} \mathrm{O}_{3} \bullet \mathrm{H}_{2} \mathrm{O}(\mathrm{am})$

\begin{tabular}{|c|c|c|}
\hline & reactions & constants \\
\hline 1 & $\mathrm{SOH}_{2}{ }^{+} \rightleftarrows \mathrm{SOH}+\mathrm{H}^{+}$ & $\log K_{\mathrm{al}}=-5.4^{a}$ \\
\hline & $\mathrm{SOH} \rightleftharpoons \mathrm{SO}^{-}+\mathrm{H}^{+}$ & $\log K_{\mathrm{a} 2}=-10.3^{a}$ \\
\hline & $\begin{array}{l}\mathrm{SOH}+\mathrm{Na}^{+} \rightleftarrows \\
\left(\mathrm{SO}^{-}-\mathrm{Na}^{+}\right)^{0}+\mathrm{H}^{+}\end{array}$ & $\log * \tilde{K}_{\mathrm{Na}}=-8.6(1.7)^{a, b}$ \\
\hline 4 & $\begin{array}{c}\mathrm{SOH}+\mathrm{NO}_{3}^{-}+\mathrm{H}^{+} \rightleftarrows \\
\left(\mathrm{SOH}_{2}^{+}-\mathrm{NO}_{3}^{-}\right)^{0}\end{array}$ & $\log * K_{\mathrm{NO}_{3}}=7.5(2.1)^{a, b}$ \\
\hline 5 & $\begin{array}{c}\mathrm{SOH}+\mathrm{CO}_{3}^{2-}+2 \mathrm{H}^{+} \rightleftarrows \\
\left(\mathrm{SOH}_{2}^{+}-\mathrm{HCO}_{3}^{-}\right)^{0}\end{array}$ & $\log * K_{\mathrm{HCO}_{3}}=20.7(5.0)^{b}$ \\
\hline 6 & $\begin{array}{l}\mathrm{SOH}+\mathrm{CO}_{3}{ }^{2-}+2 \mathrm{H}^{+} \\
\left(\mathrm{SOH}-\mathrm{H}_{2} \mathrm{CO}_{3}{ }^{*}\right)^{0}\end{array}$ & $\log * K_{\mathrm{H}_{2} \mathrm{CO}_{3}}{ }^{*}=20.0(3.2)^{b,}$ \\
\hline 7 & $\underset{\left(\mathrm{SOH}_{2}^{+}-\mathrm{CrO}_{4}{ }^{2-}\right)^{-}}{\mathrm{SOH}}+\mathrm{CrO}^{2-}+\mathrm{H}^{+} \rightleftarrows$ & $\log * K_{\mathrm{CrO}_{4}}=10.1(4.7)^{b}$ \\
\hline 8 & $\begin{array}{c}\mathrm{SOH}+\mathrm{CrO}_{4}{ }^{2-}+2 \mathrm{H}^{+} \rightleftarrows \\
\left(\mathrm{SOH}_{2}^{+}-\mathrm{HCrO}_{4}^{-}\right)^{0}\end{array}$ & $\log * K_{\mathrm{HCrO}_{4}}=19.3(7.5)^{b}$ \\
\hline 9 & $\underset{\left(\mathrm{SOH}_{2}^{+}-\mathrm{SO}_{4}{ }^{2-}\right)^{-}}{\mathrm{SOH}}+\mathrm{SO}^{2-}+\mathrm{H}^{+} \rightleftharpoons$ & $\log * K_{\mathrm{SO}_{4}}=11.6(6.2)^{b}$ \\
\hline & $\underset{\left(\mathrm{SOH}_{2}^{+}-\mathrm{HSO}_{4}^{-}\right)^{0}}{\mathrm{SOH}+\mathrm{SO}^{2-}+2 \mathrm{H}^{+}}$ & $\log * K_{\mathrm{HSO}_{4}}=17.3(10.0)^{b}$ \\
\hline 11 & $\underset{\left(\mathrm{SO}^{-}-\mathrm{Ca}^{2+}\right)^{+}}{\mathrm{SOH}}+\mathrm{H}^{+}$ & $\log * K_{\mathrm{Ca}}=-6.3(4.0)^{b}$ \\
\hline
\end{tabular}

${ }^{a}$ Constants derived in Girvin et al. (15). ${ }^{b}$ The $\log K$ values in parentheses correspond to adsorption reactions for which hydrolysis reactions for the adsorbing species and/or surface ionization reactions have been subtracted out. ${ }^{\circ}$ Like the convention used for aqueous solutions $\left[\mathrm{H}_{2} \mathrm{CO}_{3}{ }^{*}=\mathrm{H}_{2} \mathrm{CO}_{3}+\mathrm{CO}_{2}\right.$ (aq) (17)], SOH$\mathrm{H}_{2} \mathrm{CO}_{3}{ }^{*}$ suggests that the surface complex consists of a mixture of the species $\mathrm{SOH}-\mathrm{H}_{2} \mathrm{CO}_{3}$ and $\mathrm{SOH}-\mathrm{CO}_{2}(\mathrm{aq})$, which are experimentally indistinguishable. In keeping with this definition, reaction 6 may be expressed equivalently as $\mathrm{SOH}+\mathrm{CO}_{3}{ }^{2-}+2 \mathrm{H}^{+} \rightleftarrows \mathrm{SOH}-$ $\mathrm{CO}_{2}(\mathrm{aq})+\mathrm{H}_{2} \mathrm{O}\left[{ }^{*} K_{\mathrm{CO}_{2}(\mathrm{aq})}\right]$.

of $\mathrm{Fe}_{2} \mathrm{O}_{3} \cdot \mathrm{H}_{2} \mathrm{O}(\mathrm{am})$ were adjusted with acid and base to the desired $\mathrm{pH}$ and allowed to equilibrate for $4 \mathrm{~h}$ with $\mathrm{CO}_{2}(\mathrm{~g})$. Solution analysis for inorganic $\mathrm{C}$ verified equilibrium with $P_{\mathrm{CO}_{2}}=10^{-2.46} \mathrm{~atm}$. Chromate $\left(5.0 \times 10^{-6} \mathrm{M}\right)$ was added to each of the suspensions, which were stirred, open to the atmosphere, for $4 \mathrm{~h}$. After this period, the final $\mathrm{pH}$ was measured, and replicate aliquots were removed from each suspension for $\mathrm{CrO}_{4}{ }^{2-}$ analysis.

The influence of $\mathrm{H}_{4} \mathrm{SiO}_{4}\left(0.8 \times 10^{-3} \mathrm{M}\right)$ on $\mathrm{CrO}_{4}{ }^{2-}$ adsorption was evaluated as a function of $\mathrm{H}_{4} \mathrm{SiO}_{4}$ contact time with $\mathrm{Fe}_{2} \mathrm{O}_{3} \cdot \mathrm{H}_{2} \mathrm{O}$ (am). Silicic acid was prepared by basic hydrolysis of sodium metasilicate $\left(\mathrm{Na}_{2} \mathrm{SiO}_{3} \cdot 9 \mathrm{H}_{2} \mathrm{O}\right)$. The silica stock solution was $1.0 \mathrm{M}$ in concentration with a $\mathrm{pH}>13$. The degree of silica polymerization in the stock solution was not evaluated. The influence of the simultaneous cosorption of $\mathrm{H}_{4} \mathrm{SiO}_{4}$ on $\mathrm{CrO}_{4}{ }^{2-}$ was determined by spiking an $\mathrm{Fe}_{2} \mathrm{O}_{3} \cdot \mathrm{H}_{2} \mathrm{O}(\mathrm{am})$ suspension (aged $\sim 14 \mathrm{~h}$ ) with the two ions simultaneously and immediately measuring the adsorption edge. Subsequently, individual aliquots of freshly prepared iron suspension were allowed to age at $\mathrm{pH} 7$ in the presence of the same concentration of $\mathrm{H}_{4} \mathrm{SiO}_{4}$ for 24, 168, and $672 \mathrm{~h}$ under $\mathrm{N}_{2}$. After aging, the suspension $\mathrm{pH}$ was adjusted back up to $\mathrm{pH} 10$, and a typical adsorption experiment was conducted after the addition of $\mathrm{CrO}_{4}{ }^{2-}$ and ${ }^{51} \mathrm{CrO}_{4}{ }^{2-}$.

In the cation experiments the basic adsorption procedure was followed, but $5.0 \times 10^{-3} \mathrm{M} \mathrm{K}^{+}, \mathrm{Mg}^{2+}$, and $\mathrm{Ca}^{2+}$ were
Table III. Aqueous Speciation Reactions and Equilibrium Constants

\begin{tabular}{|c|c|}
\hline reaction & $\log K^{a}$ \\
\hline 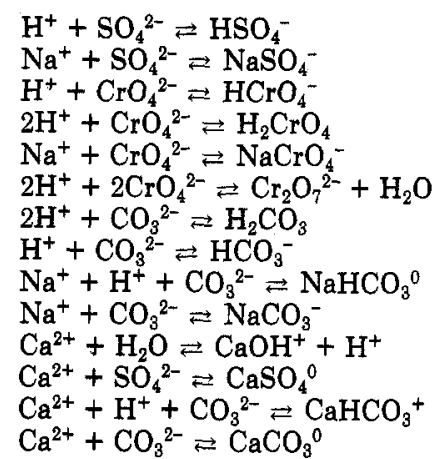 & $\begin{array}{r}1.99 \\
0.70 \\
6.51^{b} \\
5.56^{c} \\
0.70^{c} \\
14.56^{c} \\
16.68 \\
10.33 \\
10.08 \\
1.27 \\
-12.60 \\
2.31 \\
11.33 \\
3.15\end{array}$ \\
\hline
\end{tabular}

${ }^{a}$ From Truesdell and Jones, Ball, Nordstrom, and Jenne, and Ball, Jenne, and Cantrell (18-20) and Krupka and Jenne (21). ${ }^{b}$ Baes and Mesmer (22). ${ }^{c}$ Schmidt (23).

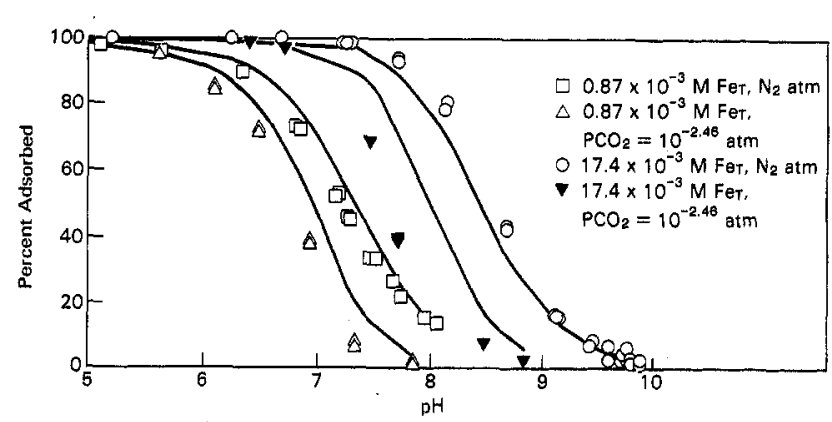

Figure 1. Fractional adsorption of $5.0 \times 10^{-6} \mathrm{M} \mathrm{CrO}_{4}{ }^{2-}$ on $\mathrm{Fe}_{2} \mathrm{O}_{3}$. $\mathrm{H}_{2} \mathrm{O}(\mathrm{am})$ in $0.1 \mathrm{M} \mathrm{NaNO}_{3}$. Experimental data points are shown by symbols. The solid curves were calculated from the model defined in Tables I-III; the adjustable parameters for the model were determined from the data represented by the open squares and open circles.

added to $\mathrm{Fe}_{2} \mathrm{O}_{3} \cdot \mathrm{H}_{2} \mathrm{O}(\mathrm{am})$ suspensions individually as the nitrate salt immediately preceding the addition of chromate.

(C) Multiple-Solute Adsorption. Chromate $(5.0 \times$ $10^{-6} \mathrm{M}$ ) adsorption on $\mathrm{Fe}_{2} \mathrm{O}_{3} \cdot \mathrm{H}_{2} \mathrm{O}(\mathrm{am})$ was investigated from two multiple-solute mixtures: (1) $2.5 \times 10^{-3} \mathrm{M}$ $\mathrm{CaSO}_{4}(\mathrm{aq})$ and $P_{\mathrm{CO}_{2}}=10^{-2.46} \mathrm{~atm}$ and (2) $2.5 \times 10^{-3} \mathrm{M}$ $\mathrm{CaSO}_{4}(\mathrm{aq}), P_{\mathrm{CO}_{2}}=10^{-2.46}$ atm, and $8.0 \times 10^{-4} \mathrm{M} \mathrm{H}_{4} \mathrm{SiO}_{4}$. The experiments were performed as described above for the $\mathrm{CrO}_{4}{ }^{2-}-\mathrm{CO}_{2}(\mathrm{~g})$ system, except that $\mathrm{CaSO}_{4}(\mathrm{aq})$ and $\mathrm{H}_{4} \mathrm{SiO}_{4}$ were added immediately preceding $\mathrm{CrO}_{4}{ }^{2-}$.

(D) Modeling of Adsorption Data. The triple-layer model (TLM) (14) has been used to simulate the adsorption data. The TLM parameters for $\mathrm{Fe}_{2} \mathrm{O}_{3} \cdot \mathrm{H}_{2} \mathrm{O}(\mathrm{am})$ are listed in Table I. Surface hydrolysis and complexation of the supporting electrolyte $\left(\mathrm{NaNO}_{3}\right)$ are described by reactions 1-4 in Table II. The equilibrium constants for these reactions were derived from potentiometric titration data for $\mathrm{Fe}_{2} \mathrm{O}_{3} \cdot \mathrm{H}_{2} \mathrm{O}$ (am) (15). Surface complexation reactions 5-11 (Table II) have been used to describe the adsorption data presented below. The equilibrium constants for these reactions have been derived from singleor paired-solute adsorption data with FITEQL (16) and the aqueous speciation reactions in Table III. These constants have in turn been used to simulate multiple-solute adsorption data. It has been assumed throughout that all adsorbing ions interact with a single set of surface sites, SOH.

\section{Results and Discussion}

Single-Solute Adsorption of Inorganic Carbon on $\mathrm{Fe}_{2} \mathrm{O}_{3} \cdot \mathrm{H}_{2} \mathbf{O}(\mathrm{am})$. The presence of $\mathrm{CO}_{2}(\mathrm{~g})\left(P_{\mathrm{CO}_{2}}=10^{-2,46}\right.$ 


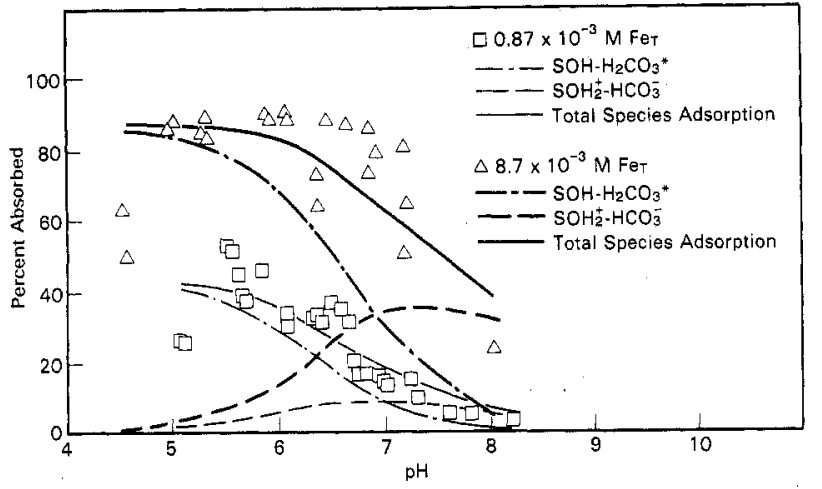

Figure 2. Closed-system adsorption of carbonate species $\left(\left[\mathrm{C}_{T}\right]=4.6\right.$ $\times 10^{-6} \mathrm{M}$ ) on $\mathrm{Fe}_{2} \mathrm{O}_{3} \cdot \mathrm{H}_{2} \mathrm{O}(\mathrm{am})$ in $0.1 \mathrm{M} \mathrm{NaNO}$. Data points are shown by symbols, and solid and dashed curves represent the optimum fit for total and indlvidual species adsorption, respectively.

atm) moves the $\mathrm{CrO}_{4}{ }^{2-}$ adsorption edge to lower $\mathrm{pH}$ relative to that obtained under $\mathrm{N}_{2}$ atmosphere (Figure 1). This effect of $\mathrm{CO}_{2}(\mathrm{~g})$ suggests that aqueous carbonate species are adsorbed and that they influence $\mathrm{CrO}_{4}{ }^{2-}$ adsorption via electrostatic interactions or competitive mass action for surface sites (SOH).

The measurement of ${ }^{14} \mathrm{C}$ removal from ${ }^{14} \mathrm{C}$-labeled $\mathrm{NaHCO}_{3}$ solutions provides direct evidence for the adsorption of aqueous carbonate species by $\mathrm{Fe}_{2} \mathrm{O}_{3} \cdot \mathrm{H}_{2} \mathrm{O}(\mathrm{am})$ (Figure 2). An adsorption maximum occurs in the region of the $\mathrm{pK} \mathrm{a}_{\mathrm{a} 1}\left(\mathrm{H}_{2} \mathrm{CO}_{3}{ }^{*}\right)=6.3$, a positioning that is similar to that observed for $\mathrm{H}_{3} \mathrm{BO}_{3}$ and $\mathrm{H}_{4} \mathrm{SiO}_{4}(24,13)$. The phenomenon differs, however, because $\mathrm{H}_{2} \mathrm{CO}_{3}{ }^{*}\left[=\mathrm{CO}_{2}(\mathrm{aq})+\right.$ $\mathrm{H}_{2} \mathrm{CO}_{3}$ ] is a stronger acid, exists primarily as $\mathrm{CO}_{2}(\mathrm{aq})(\sim$ $99 \%$ at $25^{\circ} \mathrm{C}$ ), and undergoes a change in structure as given by the combined hydration and dissociation reaction:

$$
\mathrm{O}=\mathrm{C}=\mathrm{O}(\mathrm{aq})+\mathrm{H}_{2} \mathrm{O} \Longrightarrow \mathrm{O}=\mathrm{C}>_{\mathrm{OH}}^{\mathrm{O}^{-}}+\mathrm{H}^{+} K_{m 1}=10^{-6.3}
$$

The adsorption of inorganic carbon species (Figure 2) can be described with the TLM by reactions 5 and 6 (Table II). The adsorption constants for these reactions $* K_{\mathrm{HCO}_{3}}$ and $* K_{\mathrm{H}_{2} \mathrm{CO}_{3}}$ (Table II) were derived from both sets of data in Figure 2 with FITEQL. Reactions 5 and 6 qualitatively reproduce the increase in inorganic carbon adsorption from $\mathrm{pH} 8$ to $\mathrm{pH}$ 5.5. They fail, however, to predict the decline that is suggested by the sparse experimental data below $\mathrm{pH}$ 5.5. Neither reaction 5 .nor reaction 6 alone could adequately describe both the 0.87 and $8.7 \mathrm{mM} \mathrm{Fe}$ data. Inclusion of a reaction yielding $\mathrm{SOH}_{2}{ }^{+}-\mathrm{CO}_{3}{ }^{2-}$ with reactions 5 and 6 did not improve the fit because no data above $\mathrm{pH} 8$ were obtained where this species might dominate. The Boltzmann factors for $\mathrm{H}^{+}$and $\mathrm{CO}_{3}{ }^{2-}$ ions in the TLM that describe the electrostatic interaction between the ions and the charged surface cancel in reaction 6 . Thus, the location of the $\mathrm{H}_{2} \mathrm{CO}_{3}$ * surface complex is not specified within the context of the TLM. The success of this reaction in describing the inorganic carbon adsorption data is not inconsistent with $\mathrm{H}_{2} \mathrm{CO}_{3}{ }^{*}$ forming an inner-sphere complex.

The discrepancies in describing the adsorption of dissolved carbonate species on $\mathrm{Fe}_{2} \mathrm{O}_{3} \cdot \mathrm{H}_{2} \mathrm{O}$ (am) reflect uncertainty about the bonding environment and the types of surface complexes formed on the oxide surface. This uncertainty is evident in the literature. Potentiometric titration of alumina suspensions indicates that carbonate species are specifically adsorbed (25). Infrared and Raman spectroscopy suggest that the surface complexes contain the carbonate ion in multiple-bonding environments (26). Similarly, infrared analysis of sorbed $\mathrm{CO}_{2}(\mathrm{~g})$ on hydrated

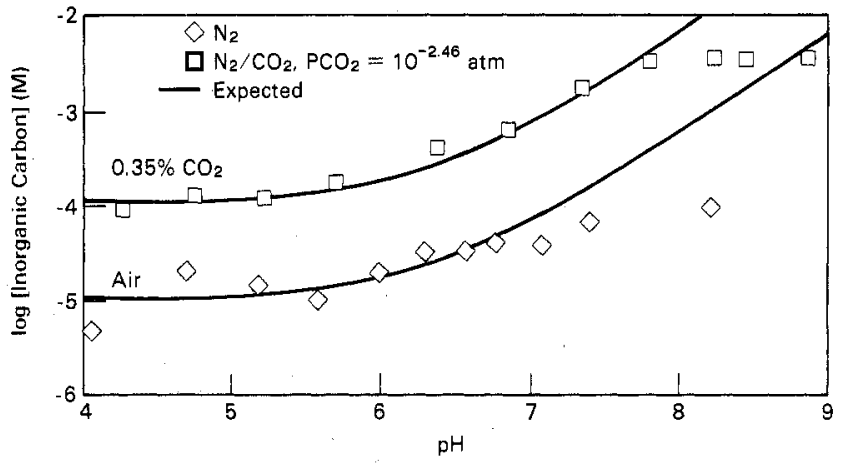

Figure 3. Measured inorganic carbon in selected experiments. Solid lines represent expected values in equilibrium with the stated atmospheric composition.

goethite surfaces suggests the formation of both $\mathrm{HCO}_{3}{ }^{-}$and $\mathrm{CO}_{3}{ }^{2-}$ surface complexes (27). The reaction of $\mathrm{CO}_{2}(\mathrm{aq})$ with goethite is postulated by Russell et al. (27) to be via coordination of the carbon atom with the triply coordinated oxide ion $\left(\mathrm{O}^{2-}\right)$ exposed in the $(001)$ grove on the (100) face and subsequent hydrogen bonding of the two oxygen atoms with proximate (A-type) surface hydroxyl groups of the geothite. $\mathrm{A} \mathrm{CO}_{3}{ }^{2-}$ surface complex is thus formed, which, like phosphate, is especially stable. Additionally, infrared spectroscopy of adsorbed inorganic carbon on freshly precipitated $\mathrm{Fe}_{2} \mathrm{O}_{3} \cdot \mathrm{H}_{2} \mathrm{O}(\mathrm{am})(28)$ indicates that the dominant surface complex is the carbonate ion bonded as a unidentate ligand to surface Fe. This evidence, taken collectively, suggests a complex-bonding environment for inorganic carbon species on oxide surfaces. This environment may necessitate different types of surface coordination sites in addition to the single $\mathrm{SOH}$ used above.

Paired-Solute Adsorption. (A) Influence of $\mathrm{CO}_{2}(\mathrm{~g})$ on $\mathrm{CrO}_{4}{ }^{2-}$ Adsorption. Given the influence of $\mathrm{CO}_{2}(\mathrm{aq})$ on $\mathrm{CrO}_{4}{ }^{2-}$ adsorption (Figure 1), the total aqueous-phase inorganic carbon $\left[\mathrm{C}_{\mathrm{T}}\right.$ ] was determined for the experimental conditions used in this study. Substantial $\mathrm{CO}_{2}(\mathrm{aq}) \mathrm{re}-$ mained in the iron suspension under $\mathrm{N}_{2}(\mathrm{~g})$ despite sparging (Figure 3). Thus, $\mathrm{CrO}_{4}{ }^{2-}$ adsorption under an $\mathrm{N}_{2}$ atmosphere (Figure 1) is a paired-rather than a single-solute system.

The curves for $\mathrm{N}_{2}$ atmosphere in Figure 1 represent the optimum fit to both 0.87 and $17.4 \mathrm{mM} \mathrm{Fe}_{\mathrm{T}}$ adsorption edges with reactions 7 and 8 in Table II. The surface reactions and the associated adsorption constants derived above for inorganic carbon, along with appropriate $\left[\mathrm{C}_{\mathrm{T}}\right]$ data, were included in this optimization. Reactions 5-8 (and associated adsorption constants) were used to describe the $\mathrm{CrO}_{4}{ }^{2-}$ adsorption data in Figure 1 with $P_{\mathrm{CO}_{2}}=10^{-2.46}$ atm. These calculations qualitatively predict the shift in adsorption but fail to predict the observed $\Delta \mathrm{pH}_{50}$, particularly for the higher iron case; the $\Delta \mathrm{pH}_{50}$ is the shift in $\mathrm{pH}$ at which $50 \%$ adsorption occurs relative to the corresponding $\mathrm{N}_{2}$ atmosphere edge.

The $\mathrm{HCO}_{3}{ }^{-}$surface complex reduces $\mathrm{CrO}_{4}{ }^{2-}$ adsorption by an electrostatic effect, displacing the edge to lower $\mathrm{pH}$ as $P_{\mathrm{CO}_{2}}$ increases. Competition between chromate surface complexes and $\mathrm{H}_{2} \mathrm{CO}_{3}$ * or $\mathrm{HCO}_{3}^{-}$surface complexes was not found to be significant in model calculations because uncomplexed sites ( $\mathrm{SOH}$ ) are in excess for all experimental conditions in Figure 1. The importance of electrostatic over competitive effects is substantiated by the observation that reaction 5 alone (Table II), which leads to the formation of a charged complex, predicts the same $\mathrm{CrO}_{4}{ }^{2-}$ $\Delta \mathrm{pH}_{50}$ as that obtained for reactions 5 and 6 . Reaction 6 , however, is essential for describing the carbonate adsorption in Figure 2. 


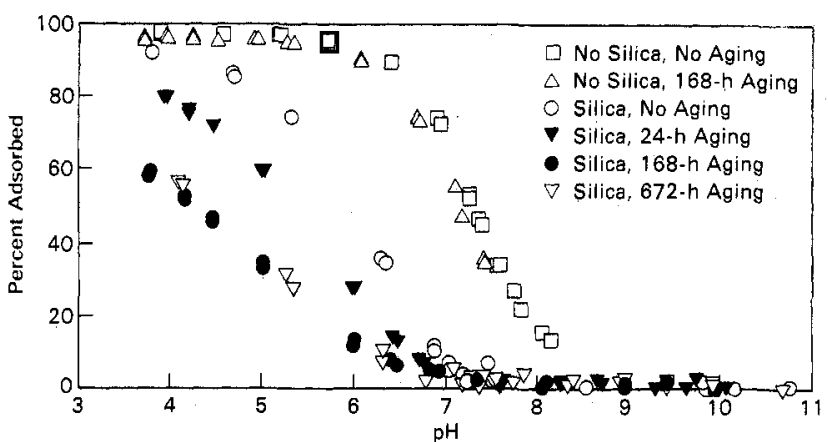

Figure 4. Adsorption of $5.0 \times 10^{-6} \mathrm{M} \mathrm{CrO}_{4}{ }^{2-}$ on $\mathrm{Fe}_{2} \mathrm{O}_{3} \cdot \mathrm{H}_{2} \mathrm{O}(\mathrm{am})(0.87$ $\left.\times 10^{-3} \mathrm{M} \mathrm{Fe}_{\mathrm{T}}\right)$ in $0.1 \mathrm{M} \mathrm{NaNO}_{3}$ under $\mathrm{N}_{2}(\mathrm{~g})$ atmosphere with and without $0.71 \times 10^{-3} \mathrm{M} \mathrm{H}_{4} \mathrm{SiO}_{4}$

The adsorption constants for sulfate and calcium corresponding to reactions 9-11 in Table II were derived from experiments (data not shown) similar to those for $\mathrm{CrO}_{4}{ }^{2-}$ adsorption. Inorganic carbon in these experiments was comparable to that in Figure 3. To account for the presence of inorganic carbon, reactions 5 and 6 and carbonate adsorption constants derived above were explicitly included when deriving the sulfate and calcium adsorption constants.

(B) Influence of Silicic Acid on $\mathrm{CrO}_{4}{ }^{2-}$ Adsorption. Like inorganic carbon, $\mathrm{H}_{4} \mathrm{SiO}_{4}(\mathrm{aq})$ depresses $\mathrm{CrO}_{4}{ }^{2-}$ adsorption (Figure 4). The largest reduction adsorption occurs at $\mathrm{pH} 6.3$, where the adsorption density decreases from 5.60 to $2.00 \mathrm{mmol}$ of $\mathrm{Cr} / \mathrm{mol}$ of $\mathrm{Fe}$. A larger effect occurs if the $\mathrm{Fe}_{2} \mathrm{O}_{3} \cdot \mathrm{H}_{2} \mathrm{O}(\mathrm{am})$ is aged with $\mathrm{H}_{4} \mathrm{SiO}_{4}$ before $\mathrm{CrO}_{4}{ }^{2-}$ addition. The aging induces a systematic decrease in $\mathrm{CrO}_{4}{ }^{2-}$ adsorption up to $168 \mathrm{~h}$, after which time additional aging up to $672 \mathrm{~h}$ has no further influence (Figure 4). In contrast, aging the iron suspension in $0.1 \mathrm{M} \mathrm{NaNO}_{3}$ under $\mathrm{N}_{2}(\mathrm{~g})$ for $168 \mathrm{~h}$ does not affect $\mathrm{CrO}_{4}{ }^{2-}$ adsorption. This time-dependent reaction of silicic acid with iron reduces the maximum $\mathrm{CrO}_{4}{ }^{2-}$ adsorption at $\mathrm{pH} 4$ from 5.5 to $3.5 \mathrm{mmol}$ of $\mathrm{Cr} / \mathrm{mol}$ of $\mathrm{Fe}$.

The decrease in $\mathrm{CrO}_{4}{ }^{2-}$ adsorption induced by $\mathrm{H}_{4} \mathrm{SiO}_{4}$ reflects the adsorption of silica and its effects on the iron surface. Silicic acid has been shown to adsorb strongly on oxide surfaces, with a broad maximum occurring near $\mathrm{pH}$ $9(13,28-32)$. Freshly precipitated iron oxides exhibit a high capacity for silicate $(33,34)$. Silica adsorption alters the surface charge and the $\mathrm{pH}_{\mathrm{zpc}}$, as shown by the displacement of alkalimetric titration curves to lower $\mathrm{pH}$ values (13). Thus, like $\mathrm{H}_{2} \mathrm{CO}_{3}{ }^{*}$ (this paper) and $\mathrm{SO}_{4}{ }^{2-}$ (5), silica consumes surface sites and forms a charged surface complex that reduces positive interfacial charge and decreases the electrostatic attraction of the $\mathrm{CrO}_{4}{ }^{2-}$ anion.

The aging effect with $\mathrm{H}_{4} \mathrm{SiO}_{4}$ reflects silica polymerization in solution or on the iron surface. Depolymerization of monosilicic acid present in the spiking solution may provide a renewable source of reactive monosilicic acid for continuing adsorption up to $168 \mathrm{~h}$. Alternatively, timedependent polymerization of $\mathrm{H}_{4} \mathrm{SiO}_{4}$ may occur on the $\mathrm{Fe}_{2} \mathrm{O}_{3} \cdot \mathrm{H}_{2} \mathrm{O}(\mathrm{am})$, reducing surface positive charge, changing $\mathrm{pH}_{\text {zpc }}$, and covering surface sites active in $\mathrm{CrO}_{4}{ }^{2-}$ complexation. Silica substitution in iron oxyhydroxide decreases the oxide $\mathrm{pH}_{\mathrm{zpc}}(35)$ and selinite adsorption (36). Surface polymerization and multilayer $\mathrm{H}_{4} \mathrm{SiO}_{4}$ adsorption have been observed on both iron and aluminum hydroxide and are influenced by solution $\mathrm{pH}, \mathrm{H}_{4} \mathrm{SiO}_{4}$ concentration $(29,31)$, and surface site saturation.

(C) Influence of Cations on $\mathrm{CrO}_{4}{ }^{2-}$ Adsorption. The binding of $\mathrm{CrO}_{4}{ }^{2-}$ by $\mathrm{Fe}_{2} \mathrm{O}_{3} \cdot \mathrm{H}_{2} \mathrm{O}(\mathrm{am})$ was measured separately in the presence of $\mathrm{K}^{+}, \mathrm{Ca}^{2+}$, and $\mathrm{Mg}^{2+}$ to investigate possible enhanced effects of aqueous ion pairing and cation

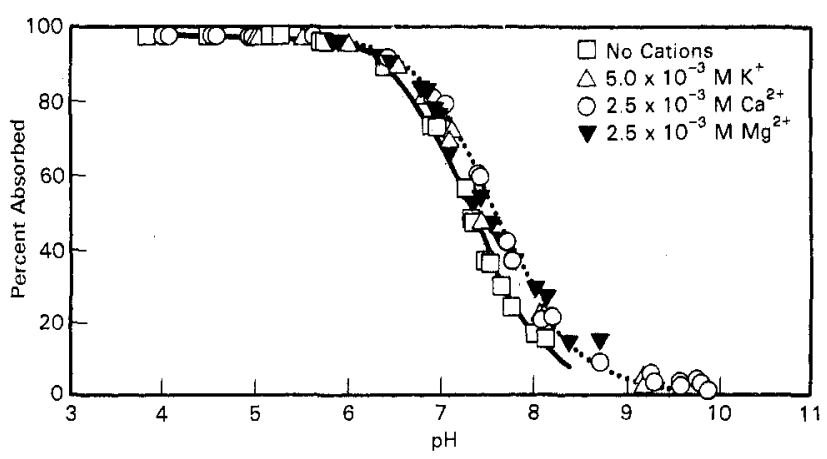

Figure 5. Influence of dissolved cations on adsorption of $5.0 \times 10^{-6}$ $\mathrm{M} \mathrm{CrO}_{4}{ }^{2-}$ by $\mathrm{Fe}_{2} \mathrm{O}_{3} \cdot \mathrm{H}_{2} \mathrm{O}(\mathrm{am})\left(0.87 \times 10^{-3} \mathrm{M} \mathrm{Fe}_{7}\right)$ in $0.1 \mathrm{M} \mathrm{NaNO}_{3}$. The solid and dotted lines represent model calculations of $\mathrm{CrO}_{4}{ }^{2-}$ adsorption in the absence and presence of $\mathrm{Ca}^{2+}$, respectively.

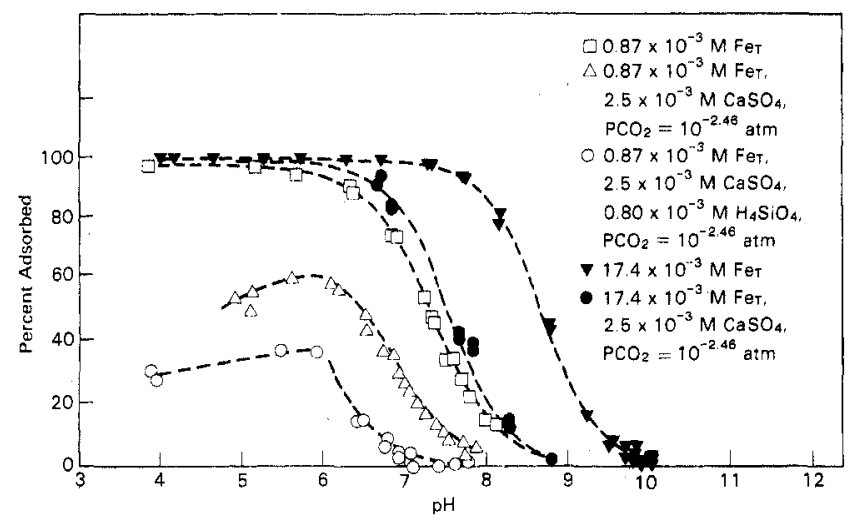

Flgure 6. Adsorption of $5.0 \times 10^{-6} \mathrm{M} \mathrm{CrO}_{4}{ }^{2-}$ on $\mathrm{Fe}_{2} \mathrm{O}_{3} \cdot \mathrm{H}_{2} \mathrm{O}(\mathrm{am})$ in 0.1 $\mathrm{M} \mathrm{NaNO}_{3}$ with and without cosolutes.

adsorption over the $0.1 \mathrm{M} \mathrm{NaNO}_{3}$ electrolyte. The cations induce a small increase in $\mathrm{CrO}_{4}{ }^{2-}$ binding (Figure 5) above $\mathrm{pH} 7$, where the adsorption of $\mathrm{CrO}_{4}{ }^{2-}$ is decreasing as that of the cations is increasing. The divalent cations have a greater effect than $\mathrm{K}^{+}$, in accordance with their higher selectivity for the iron surface $(37,38)$ over $\mathrm{Na}^{+}$. The increase, however, is slight. The overlap in the adsorption edges of $\mathrm{CrO}_{4}{ }^{2-}, \mathrm{Ca}^{2+}$, and $\mathrm{Mg}^{2+}$ from $\mathrm{pH} 7$ to $\mathrm{pH} 9$ prevents identification of the relative importance of cation adsorption vs. $\mathrm{CrO}_{4}{ }^{2-}$ cation-ion pair formation (solution or surface) on the overall retention of $\mathrm{Cr}$ (VI).

Calculations with the TLM suggest that the small shift of the $\mathrm{Cr}(\mathrm{VI})$ adsorption edge in $0.1 \mathrm{M} \mathrm{NaNO}_{3}$ after the addition of $\mathrm{K}^{+}, \mathrm{Ca}^{2+}$, and $\mathrm{Mg}^{2+}$ is consistent with an electrostatic effect induced by cation adsorption. The adsorption of $\mathrm{CrO}_{4}^{2-}$ in the presence of $\mathrm{Ca}^{2+}$ can be described (Figure 5) by reactions $1-8$ and 11 in Table II. Calcium adsorption reduces the net negative charge in the double layer over that in $0.1 \mathrm{M} \mathrm{NaNO}_{3}$ alone and thus electrostatically encourages additional anion retention. Calculations allowing for the formation of a calcium chromate surface species ( $\mathrm{SOH}+\mathrm{H}^{+}+\mathrm{Ca}^{2+}+\mathrm{CrO}_{4}^{2-} \rightleftarrows$ $\mathrm{SOH}_{2}{ }^{+}-\mathrm{CrO}_{4} \mathrm{Ca}^{0}$ ) do not improve the model simulation. These data suggest that the adsorption of aqueous $\mathrm{Ca}^{2+}-\mathrm{CrO}_{4}{ }^{2-}$ ion pairs or their formation on the surface is not significant under these conditions.

Multiple-Ion Mixtures. Chromate adsorption is lower in the ion mixture than in the paired-solute systems (Figure 6). The effects of $\mathrm{CO}_{2}(\mathrm{~g}), \mathrm{SO}_{4}^{2-}$, and $\mathrm{H}_{4} \mathrm{SiO}_{4}$ on $\mathrm{CrO}_{4}{ }^{2-}$ adsorption in the mixture are qualitatively additive. The small enhancement of $\mathrm{CrO}_{4}{ }^{2-}$ adsorption induced by $\mathrm{Ca}^{2+}$ is significant when compared to the effects of the major anions. Sulfate and $\mathrm{H}_{4} \mathrm{SiO}_{4}$ dominate the downward displacement of the adsorption edge in the ion mixture, with $\mathrm{SO}_{4}^{2-}$ inducing site saturation in the low-iron case below $\mathrm{pH}$ 6.2. Site saturation occurs when adsorbing ions 


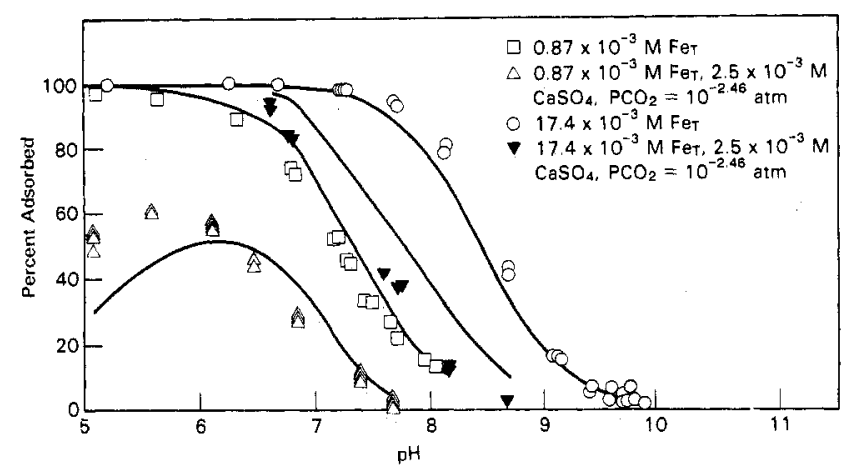

Figure 7. Adsorption modeling of $5.0 \times 10^{-6} \mathrm{M} \mathrm{CrO}_{4}{ }^{2-}$ on $\mathrm{Fe}_{2} \mathrm{O}_{3}$. $\mathrm{H}_{2} \mathrm{O}(\mathrm{am})$ in $0.1 \mathrm{M} \mathrm{NaNO}_{3}$ with and without cosolutes. Solid lines are model calculations.

significantly reduce the number of uncomplexed surface sites (SOH) and adsorption does not reach $100 \%$ at its maximum. Silicic acid has a large influence on $\mathrm{CrO}_{4}{ }^{2-}$ adsorption in the mixture below pH 8 . When higher levels of iron oxyhydroxide $\left(17.4 \times 10^{-3} \mathrm{M}\right)$ are used with the same solute concentrations, the adsorption edge for the multiple-solute system is displaced to lower $\mathrm{pH}$ relative to the edge for $\mathrm{CrO}_{4}{ }^{2-}$ as a single adsorbate, but site saturation does not occur within the experimental $\mathrm{pH}$ range $(\mathrm{pH} \geqslant 6.7)$ (Figure 6). Under these conditions, the adsorption of $\mathrm{CrO}_{4}^{2-}$ from the mixture approaches $100 \%$, but the adsorption is displaced $\left(\Delta \mathrm{pH}_{50}=1.20\right)$ to the left of its single-solute edge. The influence of inorganic carbon on $\mathrm{CrO}_{4}^{2-}$ adsorption becomes of increasing importance above $\mathrm{pH} 8.5$, because the concentrations of total dissolved carbon are relatively high $\left(\left[\mathrm{C}_{\mathrm{T}}\right]=10^{-1.3} \mathrm{M}\right)$.

The aqueous concentration of $\mathrm{SO}_{4}{ }^{2-}$ changes in the multiple-solute experiments through adsorption. Inorganic carbon is also adsorbed but is maintained at constant activity by gas-phase equilibrium. Equilibrium $\mathrm{SO}_{4}{ }^{2-}$ concentrations were observed to differ between the highand low-iron cases with a greater removal occurring with more iron. Site saturation may well have occurred in the high-iron case if major ion concentrations were held constant or if high-iron experiments were conducted at $\mathrm{pH}$ values (e.g., pH 5-6) where saturation occurred in the low-iron experiments.

Chromate adsorption in the multiple-ion mixture was calculated with the adsorption constants in Table II (see Figure 7). The constants provide excellent simulation of the adsorption edge for the low-iron case but underestimate $\mathrm{CrO}_{4}^{2-}$ adsorption below $\mathrm{pH} 6$ where $\mathrm{SO}_{4}{ }^{2-}$ is inducing site saturation. For the high-iron case, the calculation describes the shape but not the location of the edge, overestimating $\mathrm{CrO}_{4}^{2-}$ adsorption by as much as $15 \%$. This overestimate would be reduced if the formation of a $\mathrm{CO}_{3}^{2-}$ surface complex is included.

Surface speciation of $\mathrm{Fe}_{2} \mathrm{O}_{3} \cdot \mathrm{H}_{2} \mathrm{O}(\mathrm{am})$ in the multiple-ion mixture was calculated as a function of $\mathrm{pH}$ with the TLM. In the high-iron case, reactive surface sites $(\mathrm{SOH})$ remain in excess within the experimental range of $\mathrm{pH}(6.7-8.8)$ in spite of the adsorption of major ions in solution. In the absence of competition for a subset of surface sites, the shift in the edge between the two high-iron curves (Figure 7) arises from a reduction in interfacial charge imposed by the surface complexation of $\mathrm{SO}_{4}^{2-}$ and dissolved $\mathrm{CO}_{2}(\mathrm{~g})$. The reduced positive charge decreases the electrostatic attraction for all negatively charged ions, including $\mathrm{CrO}_{4}{ }^{2-}$. However, site saturation occurs in the low-iron case (Figure 8) below pH 6.2. That is, the total concentration of uncomplexed neutral sites (SOH) drops with $\mathrm{pH}$, and competition occurs among all reactive species for a limited number of sites. The resulting position and shape of the

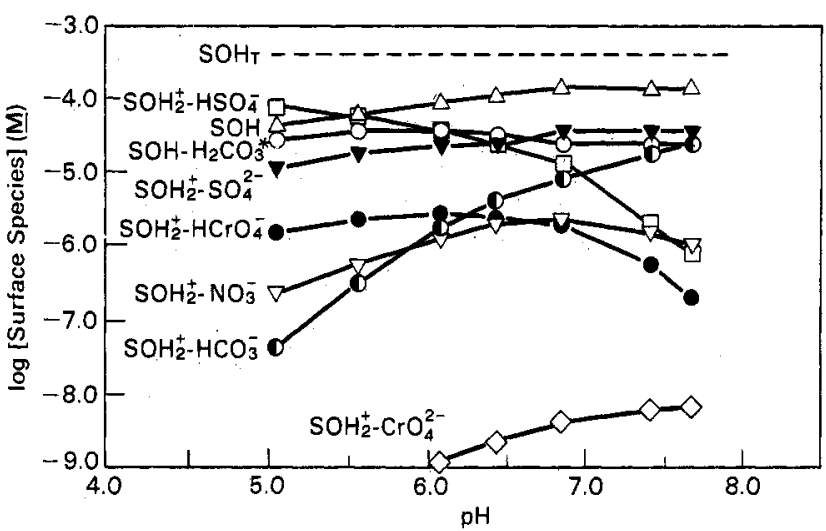

Figure 8. Calculated surface speciation of $\mathrm{Fe}_{2} \mathrm{O}_{3} \cdot \mathrm{H}_{2} \mathrm{O}(\mathrm{am})\left(0.87 \times 10^{-3}\right.$ $\mathrm{M} \mathrm{Fe}$ ) in the presence of $5.0 \times 10^{-6} \mathrm{M} \mathrm{CrO}_{4}^{2-}, 2.5 \times 10^{-3} \mathrm{M}$ $\mathrm{CaSO}_{4}(\mathrm{aq}), 0.1 \mathrm{M} \mathrm{NaNO}_{3}$, and $P_{\mathrm{CO}_{2}}=2.46 \mathrm{~atm}$. The total number of surface sites corresponding to the iron concentration is designated $\left[\mathrm{SOH}_{\mathrm{T}}\right]\left(\log \left[\mathrm{SOH}_{\mathrm{T}}\right]=-3.36 \mathrm{~mol} / \mathrm{L}\right)$.

edge are controlled by both surface electrostatics and site selectivity. The surface speciation calculations also show that $\mathrm{NO}_{3}^{-}$is an important surface species; the high electrolyte concentration drives $\mathrm{NO}_{3}^{-}$to the surface in spite of its low complexation constant (Table II).

\section{Summary}

Major groundwater anions bind to the surface of $\mathrm{Fe}_{2} \mathrm{O}_{3} \cdot \mathrm{H}_{2} \mathrm{O}(\mathrm{am})$, reduce positive charge, and compete directly with $\mathrm{CrO}_{4}{ }^{2-}$ as sites become limited. The surface reaction of these anions reduces $\mathrm{CrO}_{4}{ }^{2-}$ adsorption. In ion mixtures with solute concentrations typical of the subsurface $(39,40), \mathrm{CrO}_{4}{ }^{2-}$ adsorption is suppressed $50 \%-80 \%$ over that in weakly interacting electrolyte. Cations have little influence on $\mathrm{CrO}_{4}{ }^{2-}$ adsorption, indicating that ion pair formation in solution or on the surface is not of consequence.

Diffuse double-layer model simulations using single-solute adsorption constants are in good agreement with the experimental data from the multiple-ion mixture. Similarly, the adsorption of heavy metals $(\mathrm{Cd}, \mathrm{Pb}$, and $\mathrm{Zn})$ on goethite in synthetic seawater has been simulated with reasonable accuracy by using single-solute intrinsic adsorption constants (38). However, other calculations suggest that site heterogeneity and possibly multiple-site adsorption behavior must be considered to quantitatively simulate competition between strongly adsorbing anions (41).

Chromate adsorption in the subsurface environment may be significantly suppressed by the presence of common anionic constituents in groundwater. Elevated levels of dissolved $\mathrm{CO}_{2}(\mathrm{~g}), \mathrm{H}_{4} \mathrm{SiO}_{4}$, and $\mathrm{SO}_{4}{ }^{2-}$ may all dramatically reduce $\mathrm{CrO}_{4}{ }^{2-}$ adsorption. Surface complexation constants corrected for the influence of surface charging can be used along with diffuse double-layer models of adsorption to estimate the extent of suppression anticipated under various subsurface chemical regimes.

Registry No. $\mathrm{CrO}_{4}{ }^{2-}, 13907-45-4 ; \mathrm{Fe}_{2} \mathrm{O}_{3}, 1309-37-1 ; \mathrm{CO}_{2}$, 124-38-9; $\mathrm{H}_{4} \mathrm{SiO}_{4}, 10193-36-9 ; \mathrm{K}^{+}, 24203-36-9 ; \mathrm{Ca}^{2+}, 14127-61-8$ $\mathrm{Mg}^{2+}, 22537-22-0$.

\section{Literature Cited}

(1) U.S. Environmental Protection Agency Review of the Environmental Effects of Pollutants; U.S. Government Printing Office: Washington, DC, 1978; Vol. III, EPA 600/1-78-023.

(2) U.S. Environmental Protection Agency Quality Criteria for Water; U.S. Government Printing Office: Washington, DC, 1976; EPA 440/9-76-023.

(3) Griffin, R. A.; Au, A. K.; Frost, R. R. J. Environ. Sci. Health, Part A 1977, A12, 431-449. 
(4) MacNaughton, M. G. In Biological Implications of Metals in the Environment; Drucker, H.; Wildung, R. E., Eds.; National Technical Information Service: Springfield, VA 1977; pp 240-253; CONF-750929.

(5) Leckie, J. O.; Benjamin, M. M.; Hayes, K.; Kaufman, G.; Altman, S. Adsorption/Coprecipitation of Trace Elements from Water with Iron Oxyhydroxide; Electric Power Research Institute: Palo Alto, CA, 1980; EPRIRPP-910.

(6) Davis, J. A.; Leckie, J. O. J. Colloid Interface Sci. 1980, $74,32-43$.

(7) Mayer, L. M.; Schick, L. L. Environ. Sci. Technol. 1981, $15,1482-1484$

(8) Artiola, J.; Fuller, W. H. J. Environ. Qual. 1979, 8, 503-510.

(9) Stollenwerk, K. G.; Grove, D. B. J. Environ. Qual. 1985, $14,150-155$.

(10) Robertson, F. N. Ground Water 1975, 13, 516-527.

(11) Hingston, F. J.; Posner, A. M.; Quirk, J. P. Discuss. Faraday Soc. 1971, 52, 234-242.

(12) Stumm, W.; Kummert, R.; Sigg; L. Croat. Chem. Acta 1980, 53, 291-312.

(13) Sigg, L.; Stumm, W. Colloids Surf. 1980, 2, 101-117.

(14) Davis, J. A.; James, R. O.; Leckie, J. O. J. Colloid Interface Sci. 1978, 63, 480-499.

(15) Girvin, D. C.; Ames, L. L.; McGarrah, J. E. Neptunium Adsorption on Synthetic Amorphous Iron Oxyhydroxide; Pacific Northwest Laboratory: Richland, WA, Nov. 1984; PNL-SA-11229.

(16) Westall, J. FITEQL: A Computer Program for Determination of Chemical Equilibrium Constants from Experimental Data; Department of Chemistry, Oregon State University: Corvallis, OR, 1982; Report 82-01.

(17) Stumm, W.; Morgan, J. J. Aquatic Chemistry; Wiley: New York, 1981.

(18) Truesdell, A. H.; Jones, B. F. J. Res. U.S. Geol. Surv. 1974, 2, 233-248

(19) Ball, J. W.; Nordstrom, D. K.; Jenne, E. A. Additional and Revised Thermochemical Data and Computer Code for WATEQ2-A Computerized Chemical Model for Trace and Major Element Speciation and Mineral Equilibria of Natural Waters; U.S. Geological Survey: Menlo Park, CA 1980; Water Resources Investigations 78-116.

(20) Ball, J. W.; Jenne, E. A.; Cantrell, M. W. WATEQ3: A Geochemical Model with Uranium Added; U.S. Geological Survey: Menlo Park, CA, 1981; Open-File Report 81-1183.

(21) Krupka, K. M.; Jenne, E. A. WATEQ3 Geochemical Model: Thermodynamic Data for Several Additional Solids; Pacific
Northwest Laboratory: Richland, WA, 1982; PNL-4276.

(22) Baes, C. F., Jr.; Mesmer, R. E. The Hydrolysis of Cations; Wiley-Interscience: New York, 1976

(23) Schmidt, R. L. Thermodynamic Properties and Environmental Chemistry of Chromium; Pacific Northwest Laboratory: Richland, WA, 1984; PNL-4881.

(24) Choi, W. W.; Chen, K. Y. Environ. Sci. Technol. 1979, 13 189-196.

(25) Feldkamp, J. R.; Shah, D. N.; Meyer, S. L.; White, J. L.; Hem, S. L. J. Pharm. Sci. 1981, 70, 638-640.

(26) White, J. L.; Hem, S. L. J. Pharm. Sci. 1975, 64, 468-469.

(27) Russell, J. D.; Patterson, E.; Fraser, A. R.; Farmer, V. C. J. Chem. Soc., Faraday Trans. 1 1975, 71, 1623-1630.

(28) Harrison, J. B.; Berkheiser, V. E. Clays Clay Miner. 1982 , $30,97-102$

(29) Hingston, F. J.; Raupach, M. Aust. J. Soil Res. 1967, 5, 295-309.

(30) Beckwith, R. S.; Reeve, R. Aust. J. Soil Res. 1963, 1, 157-168.

(31) Yokoyama, T.; Nakazato, T.; Tarantani, T. Bull. Chem. Soc. Jpn. 1980, 53, 850-853

(32) Hingston, F. J.; Posner, A. M.; Quirk, J. P. J. Soil Sci. 1972 23, 177-192.

(33) McPhail, M.; Page, A. L.; Bingham, F. T. Soil Sci. Soc. Am. Proc. 1972, 36, 510-514.

(34) McKeague, J. A.; Cline, M. G. Can. J. Soil Sci. 1963, 43, 83-96.

(35) Pyman, M. A.; Bowden, J. W.; Posner, A. M. Clay Miner. $1979,14,87-92$.

(36) Anderson, P. R.; Benjamin, M. M. Environ. Sci. Technol. $1985,19,1048-1053$.

(37) Davis, J. A.; Leckie, J. O. J. Colloid Interface Sci. 1978 $67,90-107$

(38) Balistrieri, L. S.; Murray, J. W. Geochim. Cosmochim. Acta $1982,46,253-265$

(39) Hem, J. D. U.S. Geol. Surv. Water-Supply Pap. 1970, No 1473.

(40) Harmon, R. S.; White, W. B.; Drake, J. J.; Hess, J. W. Water Resour. Res. 1975, 11, 963-967.

(41) Goldberg, S. Soil Sci. Soc. Am. J. 1985, 49, 851-856.

Received for review May 7, 1986. Accepted February 6, 1987. This research was funded by the Electric Power Research Institute, Inc. (EPRI), under Contract RP2485-03, "Chemical Attenuation Studies". 